\title{
The Author's Ethical Responsibility and the Ethics of Reading
}

Jakob Lothe

University of Oslo

In Thinking Literature across Continents, Ranjan Ghosh, who teaches at the University of North Bengal in India, and J. Hillis Miller, UCI Distinguished Professor Emeritus at the University of California, Irvine, engage in a generative dialogue on a range of important topics in literary studies, including 'The Matter and Mattering of Literature' (Part I), 'Poem and Poetry' (Part II), 'Literature and the World' (Part III), and 'Teaching Literature' (Part IV). Inspired by their collaborative, fruitfully dialogical, intervention, and by 'Ethics and Literature' (Part V) in particular, this essay will discuss the narrative ethics of two narratives: Olga Horak's testimony about the Holocaust and W. G. Sebald's novel Austerlitz [2001]. While Sebald is a well-known and internationally acclaimed author, Horak is a Holocaust survivor whose story, orally transmitted to me in Sydney in 2013, is presented as written text in Time's Witnesses: Women's Voices from the Holocaust (Time's Witnesses: 116-32). Even though these narratives are very different, both are possessed of a strong ethical dimension that not only highlights the authors' sense of ethical responsibility but also, in a manner at once compelling and demanding, that of the reader. My thesis consists of three linked elements. First, even in narratives as different as these two, one non-fictional and one fictional, the author's sense of ethical responsibility is closely linked to the reader's ethical obligation. Second, as an integral part of the reader's interest in and engagement with the narrative text, this kind of obligation is generated and shaped by the narrative as textual 
structure: the author's ethical responsibility is manifested in, and presented through, narrative form (Toker 2010). Third, two of the most important constituent elements of this kind of form - that is, elements of narrative form possessed of a distinctly ethical dimension - are narrator(s) and characters, and the interplay of both with the author on the one hand and the reader on the other (Phelan 2005: 21-23).

In order to elaborate my understanding of narrative ethics, a key concept of this essay that applies equally to the author who produces the narrative and to the reader who attempts to come to terms with it, I want to highlight three features of Thinking Literature across Continents that are both inspiring for the following discussion and pertinent for literary studies overall. First, both Ghosh and Miller link their common interest in literature and ethics to practices and attitudes of reading. For Miller, the 'ethics of literature' means 'the issue of how to act or choose rightly ... the ethical dimensions of a given literary work involve a work's ethical authority over me, that is, its ability to influence my ethical acts and judgments. The ethics of a work include the author's responsibility to his readers' (Ghosh and Miller 2016: 233). The reader will notice that the key words of the quotation's last sentence all appear in the title of this essay. The author has indeed an ethical responsibility to his readers; moreover, as Miller convincingly argues in The Ethics of Reading, 'there is a necessary ethical moment in the act of reading as such, a moment neither cognitive, nor political, nor social, nor interpersonal, but properly and independently ethical' (Miller 1987: 1). If, for Miller, the 'ethical moment' is inseparable from the act of reading, it is also indistinguishable from literary form - and especially narrative form. 'Ethics', he goes on to note, 'has a peculiar relation to that form of language we call narrative' (Miller 1987: 3). Both of these points - Miller's identification of the 'ethical moment' in the act of reading and the linking of ethics to narrative form - are main concerns of the following discussion. 
Although Ghosh does not dissent from Miller's understanding of ethics in literature as 'the issue of how to act and choose rightly', and although Miller later on in his chapter specifies that 'no single concept of the ethics of literature dominates' (Ghosh and Miller 2016: 233), there are notable differences between their discussions of ethics in literature. The most interesting, and revealing, difference turns, as is often the case in literary studies, on diverging ways of approaching the concept of 'ethics'. While Miller links his understanding of the concept to 'the issue of how to act and choose rightly' in the Western critical tradition from Plato and Aristotle onwards, Ghosh starts his chapter, 'The Ethics of Reading Sahitya', by noting that 'the ethics of sahitya (literature) are inscribed in a variety of hunger. Sahitya creates its own hunger, the desire to feed on the "other" and be fed upon. It is formed out of a hunger to explicate ways of human experience and engagements with emotions' (Ghosh and Miller 2016: 207). As Mieke Bal has noted, when defined and used in a particular way, a word can become a concept, and by using the word as a concept the critic (or, as Bal might prefer to say, the literary or cultural analyst) can gain insight into what it can $d o$ (Bal 2002: 11). This is how Ghosh uses 'hunger' in his thoughtful and thought-provoking chapter. It is a concept that I find difficult to understand, partly because my lack of relevant linguistic competence and my limited perspective as a Norwegian reader and critic trained in, and thus affiliated with and limited to, the Western literary tradition. Yet for that very reason I am intrigued by Ghosh's use of the concept. As Miller notes in his response, 'the word hunger is surely, at least obscurely, a personification, as is "impregnated". A given poem or novel has a life of its own. ... "What is sahitya hungry for?" Its hunger is clearly, in any case, an outward orientation that Ghosh names "desire, motivation, and dynamicity"' (Gosh and Miller 2016: 232-33). Highlighting the author's responsibility towards the other, this outward orientation is possessed of a strong ethical element. Importantly, 'the other' here includes the reader, whose experience in the act of reading also prompts an outward orientation that is distinctly 
ethical; equally significantly, it includes the author. The different ways in which Horak (through her first-person narrative) and Sebald (via his two fictional narrators and protagonists) reach out for the other reveal, as I will suggest, elements of hunger.

Second, engaging in the critical act of comparing texts written in different languages at widely divergent periods of time, Ghosh and Miller forcibly remind me that literature is an inordinately rich resource when it comes to the challenge of communicating individual experiences, and particularly ethical questions associated with them and prompted by them, across different cultures and continents. There is a sense in which all literature is comparative literature - and this point applies not just to how literature is presented temporally and situated spatially but also, as Ghosh and Miller show, to matters language and culture. As Ghosh puts it, 'A critical negotiation between the self and the other, the native and the foreign, the insider and the outsider, is what forms culture' (Ghosh and Miller 2016: 214). Inspired by this kind of comparative critical endeavour, I will discuss two narratives written or told on two different continents (Australia and Europe); and I want to accentuate the comparative aspect by adding a non-fictional or non-literary text (Olga Horak's story) to Sebald's novel. Yet both texts are narrative texts, and ethical issues are pressing for Horak as well as Sebald.

My use of the verb 'discuss' takes me to the third feature of Reading Literature across Continents that I find inspiring. Although the wide range of issues considered by Ghosh and Miller makes it difficult for them to engage in close reading, they both suggest that the value of literature (and of other forms of text) is closely associated with, and in actual fact dependent on, careful reading and rereading; this is the kind of discussion that, it seems to me, they aim to conduct. That this task requires concentration and patience does not make it less important. It is hard to keep one's attention on the text, and it is even harder if by 'text' we mean not just the text itself but also the way in which it is historically and culturally framed. 
Yet there are, as their book shows, rich rewards of reading closely. As regards narrative texts, some, though not all, of these rewards are linked to my understanding of hermeneutics as a form of interpretative practice that accentuates the ethics of narratives. As Hanna Meretoja has shown, narratives themselves 'are about interpreting human possibilities and modes of being in the world' (Meretoja 2017: 136; compare Meretoja 2018); narratives' forms of interpretation inspire the critic's interpretative efforts by entering into dialogue with his or her reading. In Fiction and Repetition, J. Hillis Miller writes appreciatively of the philological dimension of literary studies (Miller 1982: 21; compare Miller 2013: 13-24). A branch of philology, literary studies as practised by Ghosh and Miller insists on careful reading; it privileges literary and cultural analysis. Observable in all five parts of Thinking Literature across Continents, the need for close reading seems especially strong in Part V. To put this another way, it becomes particularly pressing for the critic who aims to discuss the ethics of literary texts. One reason is that these ethical issues are inseparable from the author's presentation of them, and through the dynamics of plot formation they tend to assume the shape of questions or tensions rather than fixed positions or answers. The ethics of literature is characterized by openness as well as opacity, and often by a remarkable refusal of hegemonic practices of literary representation. It does not follow that the ethics of a literary text cannot be dubious, or even unacceptable. For me, Jonathan Littell's novel The Kindly Ones - on whose first-person narrator, a SS-officer who expresses no regrets for the murders he commits, the reader is totally dependent - approximates to such a text. In my reading of The Kindly Ones, its ethics comes close to being wrong or 'unethical' because I am unable to sufficiently separate the narrator's ethics from that of Littell as implied author (Lothe 2013: 103-18). In the two narratives under consideration here, however, there is a strong empathy with the outsider, with the poor, and with those unjustly wronged. 
Thinking Literature across Continents could perhaps be described as a variant of critique, a genre often seen 'as synonymous with literary and cultural studies, due to a shared emphasis on the values of destabilization and estrangement' (Anker and Felski 2017: 4). And yet, writing after the 'ethical turn' in literary studies, a turn to which Miller's The Ethics of Reading made a significant contribution, Ghosh and Miller develop reading strategies that, to use Paul Ricoeur's concepts, focus not just on suspicion but also on restoration, strategies that not only seek to denounce but also aim to reconstruct. When Ricoeur uses the oft-cited phrase 'hermeneutics of suspicion' in his book Freud and Philosophy, he links this variant of hermeneutics to a hermeneutics of trust or restoration (Ricoeur 1970: 27, 32). In The Limits of Critique, Rita Felski argues that in their appropriation of Ricoeur's 'hermeneutics of suspicion' practitioners of critique have tended to overlook, or critically suspend, this second constitutive element of Ricoeur's understanding of hermeneutics (Felski 2014: 1-51). Although I dissent from parts of Felski's argument, I agree that as readers and analysts we also need a hermeneutics of trust or restoration, and the variant of narrative hermeneutics adopted in this essay is influenced by Ricoeur.

Interestingly, even though they do not explicitly refer to Ricoeur, both Ghosh and Miller indicate that the need for a measure of trust or restoration becomes particularly apparent for the critic who attempts to come to terms with a text's ethics. This does not mean that as a reader I should not be 'suspicious', if by this word I mean searching for structures of meaning, attitudes, and values in the text under discussion. But this kind of searching and questioning activity needs to be accompanied by an element of trust in the author's motives and purposes as a writer, including his or her ethical responsibility. To the extent that 'suspicious' critics attempt to locate ideology in texts, I agree with Christopher Castiglia that such a critical act may, intentionally or not, remove critics 'from the act of making meaning, thereby absolving them from the responsibility for explicit ethical positions in relation to the 
time and place they study as well as their own' (Castiglia 2017: 213). Stressing the ethical aspect of literature and as well as of literary studies, Castiglia's point applies both to Thinking Literature across Continents and to the present essay. His point is important because it identifies a key aspect of critical activity. This aspect is demanding for two linked reasons. First, I may not be sure what my ethical position is; and even if I think I am I may be unable to state it explicitly by using verbal language. Second, though significant, the ethics of the text I am studying may be difficult to identify. One reason for this kind of challenge is that, as indicated already, fictional narratives tend to present ethical issues as questions - and not least as questions that cannot be easily answered. As we shall see, Sebald's Austerlitz is an illustrative example of this kind of narrative. Yet as I will now attempt to show, the ethical value of a nonfictional narrative such as Olga Horak's is also shaped just as - if not more forcibly by the questions it asks than by the answers it provides.

\section{Olga Horak's narrative - fragments and episodes}

The need to narrate can be particularly urgent when narration appears impossible. For Olga Horak, as for all survivors of the Holocaust and other atrocities who try to relate their stories, the need to bear witness to the crimes against humanity that they have experienced is accompanied by the problems associated with doing so: How can a survivor talk or write about events so horrible as to threaten to defy description and render language unusable? How can a Holocaust survivor, who needs to look forward, engage in an act of narration that unavoidably takes her back to the camp? In Remnants of Auschwitz: The Witness and the Archive, Giorgio Agamben notes that

In Latin there are two words for 'witness'. The first word, testis, from which our word 'testimony' derives, etymologically signifies a person who, in a trial or lawsuit between two rival parties, is in the position of a third party ... The second word, superstes, designates a person who has lived through something, 
who has experienced an event from beginning to end and can therefore bear witness to it. (Agamben 2012: 17)

Both of these Latin words are applicable to the narratives of Holocaust survivors. Their narratives are examples of superstes because they report events from a period of imprisonment experienced by the survivor herself. Less obviously and yet significantly, they can also be possessed of elements of testis, for a survivor's narrative can also deal with the brutal treatment and killings of other prisoners. In Olga Horak's narrative both of these facets are observable, and in her narrative discourse they are combined in a way that serves to highlight the author's ethical responsibility. Before identifying two key aspects of this responsibility I briefly introduce Time's Witnesses.

The book was prompted by an uncomfortable sense of absence: Of the approximately 300 Jewish women and children who were deported from Norway to Auschwitz in the autumn and winter of 1942-1943, no children and no women survived. Here there is void that can never be filled. However, four Jewish women who survived the Holocaust and who settled in Norway after the war were willing to meet me and tell me their stories. They have thus come forward as time witnesses in the book, as have six Jewish women, including Olga Horak, who were all born in Europe but now live on four different continents. Since the Holocaust occurred in Europe, it comes as no surprise that many survivors wished to leave that part of the world. They spread out over large sections of the globe, and the place from which they tell their story influences their narrative perspective. To this variation in spatial perspective is added a temporal one, resulting from the fact that the women who tell their stories were born between 1921 and 1935 (Lothe 2016).

Working on Time's Witnesses, I attempted to maintain a balance between the need to give the book a unifying structure and the wish to control and influence the narrative as little 
as possible. With this as my starting-point, I asked the ten women four questions, which I sent to them before our meeting:

1. Can you describe the circumstances that led up to your arrest?

2. Can you tell me how you experienced your imprisonment?

3. Can you tell a little about your life after the war?

4. When you look back at your time in the prison camp, what do you feel it is particularly important not to forget, and what can we learn from what you and your fellow prisoners were subjected to? (Lothe 2017: 3)

Although the narratives would sometimes grind to a halt because of the pressure of the events narrated and the personal losses linked to them, I asked as few additional questions as possible during the interviews. This strategy was in consonance with my role as editor: Since the book has ten authors - each Jewish woman becomes an author, and a witness, by telling her story - it is essential that the stories are presented as first-person narratives that as written text represent, as accurately as possible, the witness's oral narration. The woman's authority as author and witness is further underlined by a full-page black-and-white photograph on the page facing the beginning of the narrative text. On the top of this page, that is the page where the witness's story begins, I give, as editor, a brief introduction to her story; this basic information is complemented by a black-and-white photograph, in smaller format, of the witness as a young woman. The juxtaposition of two photographs in the same visual field accentuates their narrative dimension: while that on the left page shows us the woman at the time of narration, that on the right presents the reader with a visual image of the same woman just before she experienced the Holocaust. The act of looking simultaneously at two photographs of the same woman enhances my ethical responsibility as a reader by also making me a viewer. If I look again at the two photographs after having read the testimony, that effect is furthered strengthened.

Olga Horak's story is introduced thus: 
Born on 11 August 1926. Deported to the collection camp Sered in August 1944 and then to Auschwitz. Sent to Kurzbach in October 1944 and then on a death march to Gross-Rosen and Dresden in late December 1944. Sent to Bergen-Belsen in the first days of January 1945 and remained there until the camp was liberated by British and Canadian forces on 15 April 1945. Lives in Sydney. (Time's Witnesses 2017: 117)

While this text is written by me as editor, the following one - Olga Horak's story - is a firstperson narrative in which she combines three narrative functions: those of author, narrator, and main character. This kind of narrative combination highlights the two aspects of her ethical responsibility that I want to stress. First, she is acutely aware of the fact that soon there will be no living survivors of the Holocaust, and thus nobody who can bear witness the way she can because she was there. This sense of ethical urgency is linked to the great temporal distance between Erzählzeit (time of narration, 2013) and erzählte Zeit (time of the narrated events, from the late 1920s onwards). Second, Horak's story reveals that the act of bearing witness is both a form of remembering and an act of remembrance. As Lawrence Langer notes in Holocaust Memories: The Ruins of Memory,

the faculty of memory functions in the present to recall a personal history vexed by traumas that thwart smooth-flowing chronicles. Simultaneously, however, straining against what we may call a disruptive memory is an effort to reconstruct a semblance of continuity in a life that began as, and now resumes what we would consider, a normal existence. (Langer 1991: 2-3)

If Horak's narrative illustrates the problem of remembering 'a personal history vexed by traumas', it also shows her insistent effort to reconstruct what Langer calls 'a semblance of continuity' in her life.

Turning to a brief discussion of three textual examples of these two facets of Horak's ethical responsibility as author, I stress my ethical responsibility as editor; and I also 
emphasize that, for me, this kind of responsibility blended into that I experienced as a listener to Horak's story, as her narratee. All the choices I made as editor were possessed of an ethical element, though this element could vary both in scope and kind. On the one hand, how could a privileged Norwegian man born after the Second World War know what questions to ask a Holocaust survivor? The truth is that I could not, and thus I could not be sure that the three questions mentioned above were the 'right' ones. On the other hand, had this problem led me to abandon the book project (without questions there would have been no stories), that decision would also have been ethically problematic since the women's testimonies are truly important.

Serving as a motivation to narrate, the 'semblance of continuity' that Langer mentions is evident in the first sentences of Horak's story: 'we had a well-functioning democracy in Czechoslovakia before the war. ... There was no persecution due to religious differences. Everybody lived in harmony' (Time's Witnesses 2017: 117). This opening establishes a powerful, in one sense almost absolute, contrast between the first twelve years of Horak's life and what happened after the German invasion. Life during the war gradually became more difficult until, in August 1944,

There were the carriages waiting for us - cattle carriages - and we were pushed in. This is the way we were transported to Auschwitz. You have probably seen a cattle carriage. What is it made for? To transport horses or cows. ...

How long it took us to reach Auschwitz, I cannot tell you. For once you are confined in a dark place, you lose your sense of timing. The doors were bolted from the outside. Inside it was horrible. We had no food or water. There was just one bucket which served for necessity. I was a young, modest girl. I could not use it. It was a horrible feeling.

When we arrived at Auschwitz, the transport of the human cargo stopped. We did not know where we were. They unbolted the doors, and the guards were shouting and screaming. You know, when they scream Schnell! Schnell! Raus, raus! ('Quickly! Quickly! Out! Out!') I did not know why we had to be schnell. What was the hurry for? There was something sick in their minds. (Time's Witnesses 2017: 121) 
In this passage, Horak's ethical responsibility as author and narrator manifests itself in two, mutually reinforcing, ways. First, in not just stating but also attempting to explain why she lost her sense of time inside the cattle carriage, she turns what superficially seems a narrative weakness into a narrative strength, thus increasing her narrative credibility while also accentuating the ethics of her narration. As cognitive narrative theory points out, the way in which the brain receives and processes a myriad of impressions is extremely complicated, and external factors (such as this brutal, inhumane kind of transport) may make it more difficult for the brain to compose plots and arrange temporal sequences that, as Paul Ricoeur puts it, can convert 'the existential burden of discordance' (Ricoeur 1984: 31; compare Armstrong 2013: 91-130) into narrative syntheses that can impose a degree of meaning on life's imbalances - imbalances which in this case, in the cattle carriage as in the camp, were extreme. How could patterns of action be constructed under such conditions? It is to Horak's credit, and it strengthens the authority of her narrative, that she narrates this part of her story as a naked, inexplicable fragment. Her refusal to re-arrange the course of events in the light of later knowledge of the mechanisms of the Holocaust makes her appear more, not less, ethically responsible. Second, the way in which Horak conveys her inability to comprehend the Nazis' haste makes the reader glimpse two radically opposed ethical systems. There is a link between this part of the passage and Primo Levi's observations in If This Is a Man on the guards' attitudes and actions in Auschwitz; after having been deported from Italy, he too arrived in the camp in 1944 (Levi 2003: 20).

Horak's testimony approximates to the genres of the fragment and the episode. That her narrative is fragmented and episodic, however, does not make it less convincing as testimony; on the contrary, as in the example considered above, its incompleteness enhances the author's ethical responsibility and authority. Without a sense of meaningful temporal continuity, events dissolve into unconnected fragments and meaningless episodes; moreover, 
even if considered as fragments and episodes, these elements of events (or non-events) do not make sense.

Yet it does not follow that the fragments and episodes Horak relates are unimportant. Rather, their significance is linked to her inability to ascribe meaning to them; more precisely, she fails to understand the motives and the ethical foundation for the actions of the human agents engaged in the fragmented, or fragment-like, events. This is the case even when the outcome of an event can literally decide between life and death:

There were many SS men waiting on the arrival ramp. They were dressed in immaculate black uniforms and polished boots. One of the SS men sat behind a table. He was in charge of the process of selecting people: sorting out people who were taken to the gas chambers shortly after arriving. He was a young, handsome man. I remember he wore leather gloves. He was Dr Josef Mengele, the 'Angel of Death'. ...

As the line I was in approached the table where Mengele sat, we were ordered to strip completely naked. That was great shock. It was degrading and humiliating. I was young and would not have undressed in front of anyone. But that was what we had to do. Now we had to form a single line and walk towards Mengele, who looked at us, deciding who was young and fit enough to be sent to the right. Anyone who was not considered good enough by Mengele was sent to the left. Those sent to the left could also be young and healthy, but maybe they had a scar or some insignificant mark. They were not 'perfect'. So we never knew what to expect.

I approached the table. Mengele looked me up and down like a butcher inspecting meat, and waved me to the right. My mother was a healthy, well-developed woman. She was shown to the right as well. I was $16 \frac{1}{2}$, and my mother 39 . We had passed the first Selektion at Auschwitz. (Time's Witnesses 2017: 122-23)

The ethical dimension of Horak's meeting with Dr Mengele is accentuated by the way in which she reports it: the rendering of facts as she now (in the narrative situation with me in Sydney in 2013) remembers them, the linking of the facts to the shock of having to undress, the comparison of Mengele's look to that of a butcher inspecting meat, the inclusion of the word Selektion. Cumulatively, these constituent elements of her narration strengthen her ethics by contrasting it with Mengele's - and by implication with that of Nazism. In addition 
to Selektion, the key word in this passage is 'mother': Not only do the two women share the experience of meeting Mengele; there is also a strong implication that they share the same values, and that the ethics of Olga's mother has contributed decisively to the formation of her own.

The importance of this point is further strengthened by Horak's narration of an episode just after the liberation of Bergen-Belsen in April 1945. Olga and her mother are waiting to be registered by British soldiers:

My mother came in front on the table. She gave her information. She received her card. She collapsed. I lost her; she did not make it.

My mother is registered as a survivor. She is not counted as a victim. I was behind her, and of course I was devastated. My mother had survived Auschwitz, Kurzbach, the death march to Dresden, and four months in Bergen-Belsen - only to die just after being registered as a survivor. My mother was 40 years old, and I was 18 . Now I was completely alone. (Time's Witnesses 2017: 128)

The narration of this episode from Bergen-Belsen is similar to that of the two women's meeting with Dr Mengle. Yet although here too the emphasis is on the actual occurrence, on what happened as remembered by the witness, here as in the episode from Auschwitz some words become semantically loaded in a way that enhances their ethical dimension. If Selektion is one such word in the earlier passage, in this one the words 'completely alone' indicate that without her mother Olga Horak would not have survived the Holocaust.

Although different readers read and interpret narratives in different ways, I think most would agree that this suggestion at the end of the paragraph is possessed of a distinctly ethical element. This element is constituted and shaped through narrative form. For me as a listener to Olga Horak's oral rendering of her story, the ethical aspect was strengthened by a long pause after the words 'completely alone'. The act of narrating how her mother died brought 
back painful memories and made it difficult for her to continue her story. That, after a pause, she eventually did, testifies to a remarkable strength of will. It also reveals a deep ethical commitment.

The reader might counter that this kind of extra-textual information, available just to me as listener and editor but not to other readers of Olga Horak's testimony, is irrelevant and potentially even misleading. It might, though, helpfully remind us of one of the strengths of oral narration - a strength of which a written narrative is not possessed. It also reminds us of the importance of thinking literature across continents: as a European I all too easily forget how important oral narrative traditions still are in other parts of the world. For me, there was also the editorial, and ethical, challenge of respecting Ola Horak's pause - a narrative ellipsis impossible to present as written language - and of not asking a question that might make her story less authentic by leading it in a direction she did not choose herself. Her pause, her temporary inability to narrate, suggests a variant of hunger operative at different yet convergent levels. At the narrated level, there is the physical hunger constantly felt in the camp; and there is the hunger for peace, for the war to be over. At the level of narration, Olga Horak's pause expresses, both as part of her narration and as a consequence of it, a hunger for reunion with her mother, though she knows this cannot happen. This kind of hunger is linked to her responsibility as an author. This is a responsibility towards the other, including the reader of her story. Thus, it is also a responsibility towards the future (Ghosh and Miller 2016: 208; compare Derrida 1992). Even though Olga Horak's story is not a literary narrative, there is a sense in which its ethics, like 'the ethics of sahitya (literature)', 'is inscribed in a variety of hunger' (Ghosh and Miller 2016: 207). Although I find it difficult to understand the variants of hunger I have identified here, variants that blend into each other in the act of reading, I have an ethical obligation to try to do so. 


\section{W. G. Sebald's Austerlitz - narrative fiction as reflection on the Holocaust}

A forceful testimony, Olga Horak's story illustrates a number of the generic markers of the genre identified by Agamben and Langer. Dependent on and arising from the form of her narrative, the ethics of her testimony is inseparable from her urge to engage in oral narration in order to document - as convincingly as possible, in spite of the fallibility and shortcomings of human memory - an appalling crime committed by citizens of a nation at the centre of European civilisation. Although relatively few German citizens were directly involved in the Holocaust, this historical event left a mark on all of them, including W. G. Sebald. Born in 1944, Sebald, the son of a German soldier who (returning home a stranger to his son in 1947) never spoke about his war experiences, was, literally as well as metaphorically, a child of the Second World War. Perhaps his father's silence, a silence that was part of a more general refusal to talk about the past in the Bavarian village where the family lived, may have been one of the factors that, many years later, motivated Sebald to write Austerlitz. If, as Walter Benjamin observes of the narrator in his classic essay 'The Storyteller' (Benjamin 1999: 8485), the traditional, oral storyteller's motivation to narrate is prompted by his or her dramatic experiences away from home - and this would surely apply to Olga Horak's story - in the case of Sebald, the author's need to narrate seems motivated by the opposed quality of absence. This kind of absence or blank forms an extended Leerstelle (a point of 'suspended connectability'), to appropriate Wolfgang Iser's concept (Iser 1980: 198). It is this blank that, because it both suspends connectability and draws attention to the underlying narrative of the war (and the Holocaust as an event made possible by the war), needs to be filled in, or rather, since that is not possible, at the very least addressed and explored through narrative. In the novel Austerlitz this narrative is written by the author; it is told by the narrator and/or one or more characters, and it is retold, or perhaps rather re-created or co-created, by a listener (who later becomes the main narrator) and the reader. As I will show, the ultimate effect is to 
implement, sustain, and gradually enhance the ethical responsibility of author and reader alike. As a complex novel, Austerlitz is of course very different from Olga Horak's testimony. Yet the ethics of the two narratives is remarkably similar; moreover, in both narratives, the anchoring point for the narrative's ethics is the protagonist's mother.

Austerlitz begins thus: 'In the second half of the 1960s I travelled repeatedly from England to Belgium, partly for study purposes, partly for other reasons which were never entirely clear to me, staying sometimes for just one of two days, sometimes for several weeks' (Sebald 2002: 1). On a first reading, we may tend to think that the first-person narrator, the 'I' who travels 'repeatedly from England to Belgium', is identical with the novel's protagonist. Yet although, as it turns out, there is a peculiar affinity between the first-person narrator and the novel's main character, whose name is identical with the novel's title, this beginning is actually a frame narrative whose main function is to establish a narrative situation in which the two can meet, in which Austerlitz can talk, and in which the first-person narrator can listen. When we start reading this novel we cannot know that while both the first-person narrator and Austerlitz are fictional narrators and characters, the 'I' who travels from England to Belgium is German and Austerlitz is Jewish. With a view to Sebald's fictional exploration of ethical responsibility, this constellation of narrators and characters proves highly significant and thematically productive. Throughout this engrossing, melancholic text, both Austerlitz and the anonymous 'I' keep searching for elements of meaning in what appears, and in one sense remains, an extended Leerstelle. The impossibility of presenting the Leerstelle directly by using written language establishes a point of contact with the pauses in Olga Horak's oral narration of her story; significant as they are, the Leerstellen are absent from the written text. They become variants of paralipsis by drawing the reader's attention to something that is not there. For Horak, this kind of vacuity is part of her experience, and therefore real; for the fictional character Austerlitz and for the German first-person narrator, 
the extended Leerstelle is closely associated with Austerlitz's persistent search for his parents even though, or perhaps rather because, he knows that in all probability both of them were murdered in the concentration camp whose first three and last three letters are part of his name (and of novel's title), Auschwitz. Austerlitz's knowledge that his search is doomed to failure seems paradoxically to strengthen his need to embark on it. While the reasons, or causes, may seem unclear, this need forcibly demonstrates a kind of hunger for the other which in Austerlitz's case essentially means his mother and father, and thus by implication his lost childhood together with his parents. In particular, the hunger for his absent mother is so strong that it forces him to search for her, travelling by train and gradually moving further and further east. In spite of the significant generic differences between the testimony and the novel, for Austerlitz as for Olga Horak, hunger includes a strong feeling of responsibility towards the other. A major gain of Sebald's narrative method in Austerlitz is the way in which Austerlitz's ethical responsibility is transferred to the first-person narrator, and then from him to the reader.

The first-person narrator first meets with Austerlitz in the railway station in Antwerp:

One of the people waiting in the Salle des pas perdus was Austerlitz, a man who then, in 1967, appeared almost youthful, with fair, curiously wavy hair of a kind I had seen elsewhere only on the German hero Siegfried in Fritz Lang's Nibelungen film. That day in Antwerp, as on all our later meetings, Austerlitz wore heavy walking boots and workman's trousers made of faded blue calico, together with a tailor-made but long outdated suit jacket. (Sebald 2002: 6-7)

This is the first mention of Austerlitz's name, or more accurately, the first repetition of the name we have read on the book's cover. The narrator presents Austerlitz as a traveller, and yet as someone who stands apart from the other travellers. As Austerlitz starts telling his story, we realize that the 'I' who travels 'repeatedly from England to Belgium' is actually a 
frame narrator who serves the dual function of narrator and narratee: after having introduced the reader to Austerlitz, he listens to Austerlitz's story and then, adding comments and reflections of his own, passes it on to the reader. Considering this narrative form as decisive for the novel's ethics, I stress the ethical significance of the narrative situation in which a Holocaust survivor tells his story to a middle-aged German man. In Story and Situation, Ross Chambers draws attention to the manner in which, at a deep and frequently unthematized level, the narrator's motivation to narrate is complemented by the narratee's readiness to listen, and that, for both parties, both possibilities of gain and risks of loss are involved (Chambers 1984: 51). Chambers's important point is particularly illuminating with a view to Austerlitz. By telling fragments of his story, Austerlitz risks confirming his sense of loss and estrangement, yet his narration may enable him to negotiate that loss. By listening the narratee risks losing, or being drawn out of, a comfortable position of ignorance, yet the fact that he not only listens to but also retells what Austerlitz has told him suggests a learning process during which he gains essential knowledge. This learning process, the first-person narrator's growth or Bildung, is possessed of elements of hunger that strengthen his ethical responsibility towards Austerlitz on the one hand and towards the reader on the other. This kind of responsibility is also an ethical obligation. That this obligation may be particularly strong for a German listener or reader does not make it unimportant for other readers across continents, especially perhaps for those born after the Second World War. If reading Olga Horak's story is a way of not forgetting the Holocaust, so is the experience of perusing Sebald's novel.

I have suggested that the ethical centre of Olga Horak's story revolves around, and is personified by, her mother. Sebald, born in Germany in 1944, uses the resource of literature to present an ethics whose most precious values are closely linked to, and represented by, Austerlitz's mother. Details of Austerlitz's origin were suppressed for a long time; it has taken 
him a lot of energy to find out that although he grew up in the Welsh village of Bala, he is actually a Czech Jew who was sent to Britain when he was only five, as part of a Kindertransport in 1939. His father, Maximilian Aychenwald, fled to France, while his mother, Agáta, remained in the Czech Republic together with Věra, a non-Jewish friend of the family.

As Austerlitz's identity search blends into a prolonged search for this childhood and his parents, he goes back to Prague, where he manages to re-establish contact with Věra. She tells him that, after tirelessly contacting everybody who could possibly help, Agáta managed to get her five-year-old son onto a Kindertransport from Prague to Britain. Věra also tells Austerlitz 'that she had learned how Agáta was sent east in September 1944 with one and half thousand others who had been interned in Terezín' (Sebald 2002: 287). Zdenka Fantlová, who tells her story in Time's Witnesses and was interned in Terezín, notes that for the camp's inmates, 'to go East' (Time's Witnesses 2017: 143) alluded to an ominous place they knew little about: Auschwitz. Although he imagines that he can see his mother's face in a propaganda film the Nazis made in Terezín, Austerlitz finds no trace of her in the camp. However, in Prague he comes upon 'the photograph of an anonymous actress who seemed to resemble my dim memory of my mother', and whom Věra recognizes as 'Agáta as she had then been' (Sebald 2002: 353, 354). Immediately after having relayed these words (which he has been told by Austerlitz who has been told by Věra), the 'I' who combines the functions of narrator and listener makes a comment that, in my reading of the novel, constitutes its ethical core:

- During this part of his tale, Austerlitz and I had walked from the cemetery behind St Clement's Hospital all the way back to Liverpool Street. When we took leave of each other outside the railway station, Austerlitz gave me an envelope which he had with him and which contained the photograph from the theatrical archives in Prague, as a memento, he said, for he told me that he was now about to go to Paris to search for traces of his father's last movements ... (Sebald 2002: 354) 
It is significant that this narrative situation, in common with that in Antwerp when they first meet, is also linked to a railway station. Railway stations and train journeys are semantically loaded for both Sebald and Horak, as in Austerlitz they are for Austerlitz and the anonymous German first-person narrator: They are inextricably linked to the transports of Jews from nearly all of Europe to the concentration and extermination camps. Horak tells about her journey to Auschwitz in a cattle carriage; in the novel, Agáta is 'sent east' in a similar way, probably under equally appalling conditions. For Austerlitz, though, The German words Zug and Bahn/Eisenbahn (meaning 'train' and 'way/railway') are semantically loaded in an ambiguous way that is not unproblematic: Before his mother was 'sent east', she managed to secure a place for her son on a train moving in the opposite direction, thus saving his life.

There is a strong sense in which Austerlitz's futile search for this mother forms the basis for the narrative situations with him and his German listener. While Austerlitz is both the novel's protagonist and a main narrator, the anonymous German man is not just a listener and narrator but also an important character - the second main character in Austerlitz. Austerlitz's fragmented narrative makes a profound impression on him, and his response is ethical to the extent of not just listening patiently to the story in a number of narrative situations but even retelling it and framing it in a way that underlines its significance, its ethical urgency.

It is as though Austerlitz's insatiable hunger for his parents blends into, and colours, the German character's need to listen to, and then narrate, Austerlitz's story. It is the reader's privilege, and obligation, to share the anonymous German character's ethical response. For Austerlitz - as for Sebald as implied author, for the German first-person narrator, and for the reader - Agáta personifies human values at the opposite extreme of those represented by Nazism. While her ethics manifests itself as care for those around her, and her son in 
particular, that of Nazism necessitates use of the word evil - the Nazis' evil actions systematically executed on a colossal scale (Vetlesen 2005). Why does Austerlitz give the photograph of his mother to a German? For me, this question constitutes the ethical core of Sebald's novel. That it cannot be easily answered enhances, rather than reduces, its significance. From the perspective of narrative hermeneutics that I adopt in this essay, there is not just one deep meaning to be unveiled in Austerlitz. Yet it does not follow that the novel, for all the melancholic resignation that pervades it, may not be possessed of elements of meaning - and Austerlitz's gift to his German friend, a friendship formed against all odds, is a meaningful, responsible, act that signals a qualified hope for the future. In my reading of Austerlitz, Sebald, via his German first-person narrator, shares, albeit perhaps hesitantly, this hope. Imbued with an element of hunger, it is deeply ethical - as is the hope of Olga Horak. Different as they are, Horak's testimony and Sebald's novel are powerful narratives that, revolving around a historical event that I have an ethical obligation not to forget, shape my view of who I am and my responsibility as a citizen of Europe.

\section{References}

Agamben, Giorgio (2012 [1998]), Remnants of Auschwitz: The Witness and the Archive, trans. Daniel Heller-Roazen, New York: Zone Books.

Anker, Elizabeth S. and Rita Felski (2017), 'Introduction', in Anker and Felski (eds), Critique and Postcritique, Durham: Duke University Press, 2017), pp. 1-28.

Armstrong, Paul B. (2013), How Literature Plays with the Brain: The Neuroscience of Reading and Art, Baltimore: Johns Hopkins University Press. 
Bal, Mieke (2002), Travelling Concepts in the Humanities: A Rough Guide, Toronto: University of Toronto Press.

Benjamin, Walter (1999 [1936]), 'The Storyteller', in Illuminations, trans. Harry Zohn, London: Pimlico, pp. 83-107.

Castiglia, Christoper (2017), 'Hope for Critique?', in Elizabeth S. Anker and Rita Felski (eds), Critique and Postcritique, Durham: Duke University Press, pp. 211-29.

Chambers, Ross (1984), Story and Situation: Narrative Seduction and the Power of Fiction, Manchester: Manchester University Press, 1984.

Derrida, Jacques (1992), Acts of Literature, ed. Derrek Attridge, London: Routledge.

Felski, Rita (2014), The Limits of Critique, Chicago: University of Chicago Press.

Ghosh, Ranjan and J. Hillis Miller (2016), Thinking Literature across Continents, Durham: Duke University Press.

Iser, Wolfgang (1980), The Act of Reading: A Theory of Aesthetic Response, Baltimore: Johns Hopkins University Press.

Langer, Lawrence L. (1991), Holocaust Testimonies: The Ruins of Memory, New Haven: Yale University Press.

Levi, Primo (2003 [1958]), If This Is a Man, trans. Stuart Woolf, London: Abacus.

Littell, Jonathan (2009), The Kindly Ones, trans. Charlotte Mandell, London: Vintage.

Lothe, Jakob (2013), 'Authority, Reliability, and the Challenge of Reading: The Narrative Ethics of Jonathan Littell's The Kindly Ones', in Jakob Lothe and Jeremy Hawthorn (eds), Narrative Ethics, Amsterdam: Rodopi, pp. 103-18. 
Lothe, Jakob (2016), 'Narrative, Testimony, Fiction: The Challenge of Not Forgetting the Holocaust', in Lia Brozgal and Sara Kippur (eds), Becoming Contemporary: French Literature, Culture, and Politics Today, Liverpool: Liverpool University Press, pp. 162-76.

Lothe, Jakob (2017), 'Introduction', in Jakob Lothe (ed), Time's Witnesses: Women's Voices from the Holocaust, Edinburgh: Fledgling Press, pp. 1-23.

Meretoja, Hanna (2017), 'Narrative Hermeneutics and the Ethical Potential of Literature', in Jakob Lothe (ed), The Future of Literary Studies, Oslo: Novus Press, pp. 135-47.

Meretoja, Hanna (2018), The Ethics of Storytelling: Narrative Hermeneutics, History, and the Possible, Oxford: Oxford University Press.

Miller, J. Hillis (1982), Fiction and Repetition: Seven English Novels, Oxford: Blackwell.

Miller, J. Hillis (1987), The Ethics of Reading: Kant, de Man, Eliot, Trollope, James, and Benjamin, New York: Columbia University Press.

Miller, J. Hillis (2013), 'Should We Read or Teach Literature Now?', in Jakob Lothe and Jeremy Hawthorn (eds), Narrative Ethics, New York: Rodopi, pp. 13-24.

Phelan, James (2005), Living to Tell about It: A Rhetoric and Ethics of Character Narration, Ithaca: Cornell University Press.

Ricoeur, Paul (1970), Freud and Philosophy: An Essay on Interpretation, trans. Denis Savage, New Haven, CT: Yale University Press.

Ricoeur, Paul (1984), Time and Narrative, volume 1, trans. Kathleen McLaughlin and David Pellauer, Chicago: University of Chicago Press.

Sebald, W. G. (2002 [2001]), Austerlitz, trans. Anthea Bell, London: Penguin.

Time's Witnesses: Women's Voices from the Holocaust (2017), ed. Jakob Lothe, Edinburgh: Fledgling Press. 
Toker, Leona (2010), Towards the Ethics of Form in Fiction: Narratives of Cultural Remission, Columbus: Ohio State University Press.

Vetlesen, Arne Johan (2005), Evil and Human Agency: Understanding Collective Evildoing, Cambridge: Cambridge University Press. 